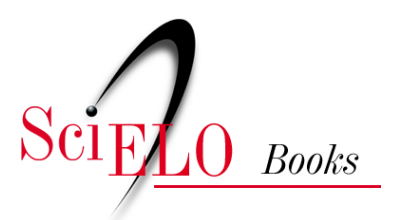

\title{
Viagem de 1929
}

\author{
José Carlos Radin \\ Gentil Corazza
}

\section{SciELO Books / SciELO Livros / SciELO Libros}

RADIN, J.C., and CORAZZA, G. Viagem de 1929. In: Dicionário histórico-social do Oeste catarinense [online]. Chapecó: Editora UFFS, 2018, pp. 140-142. ISBN: 978-85-64905-65-8. https://doi.org/10.7476/9788564905658.0035.

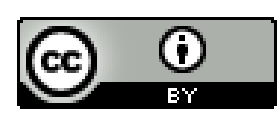

All the contents of this work, except where otherwise noted, is licensed under a Creative Commons Attribution 4.0 International license.

Todo o conteúdo deste trabalho, exceto quando houver ressalva, é publicado sob a licença Creative Commons Atribição $\underline{4.0}$.

Todo el contenido de esta obra, excepto donde se indique lo contrario, está bajo licencia de la licencia $\underline{\text { Creative Commons }}$ Reconocimento 4.0. 


\section{Viagem de 1929}

“A Viagem de 1929" foi realizada no período de 17 de abril e 18 de maio de 1929 pelo Presidente do Estado de Santa Catarina, Adolfo Konder, e uma comitiva de 20 pessoas, com o objetivo de efetivar o reconhecimento e a ocupação política da Região Oeste catarinense. Essa viagem durou 31 dias e percorreu cerca de três mil Km, partindo de Florianópolis, no litoral, até Dionísio Cerqueira, junto à divisa com a República Argentina. A comitiva era grande e diversificada, pois incluía, além da figura do Presidente do Estado, secretários de Estado, chefe de polícia, agrimensores, consultor jurídico e deputados. Entre eles figuravam Othon Gama D’Eça, Artur Ferreira da Costa e José Arthur Boiteux, que registraram suas impressões em importantes relatos. $\mathrm{Na}$ viagem, foram usados todos os meios de transporte disponíveis, como automóvel, lanchas, trem e até mula de carga.

Várias circunstâncias históricas justificavam aquela expedição, como a definição das fronteiras externas das terras brasileiras com a Argentina, ocorrida em 1895, a resolução dos conflitos sobre as fronteiras internas, entre os estados de Santa Catarina e do Paraná, bem como a pacificação da região, após o término da Guerra do Contestado, em 1916. Faltava, ainda, a ocupação política de parte do território, a ser feita pelo governo do Estado, ocupação a qual foi realizada de forma pouco usual, através de uma viagem de reconhecimento, que ficou conhecida como "A Viagem de 1929". Essa viagem pretendia ser uma "Marcha para o Oeste", uma tomada de posse de um espaço ainda desconhecido do poder público, que, pelo seu significado, deixou marcas profundas nos sentimentos e na imaginação popular da região. Associados ao objetivo maior da viagem, que foi a ocupação política da região por parte do governo estadual, somavam-se outros objetivos, como criar condições para o reconhecimento e a integração do território, abertura de estradas, escolas, agência postal, e implantação do telégrafo, além de impor a ordem e disciplina no Oeste, transformando uma "terra da barbárie" em uma "terra do trabalho", como foi definido por integrantes da mesma. A viagem deveria, ainda, procurar 
exercer a soberania sobre as terras do Oeste, incentivar a construção da brasilidade, preencher o vazio demográfico e apagar os últimos vestígios dos velhos rancores originados dos muitos conflitos, que dominaram a região. Tratava-se, enfim, de levar o processo civilizador para o interior do Estado.

Nas palavras de D’Eça (1992), membro da comitiva, a região era "inculta e desconhecida", mas, como uma "nova Canaã, convida, assegurando remuneradores resultados, a cooperação da inteligência e do braço do homem disposto a trabalhar". Outro membro da comitiva oficial (Costa, 1929) afirma que a Viagem visava a "implantação da ordem, o respeito às leis, ao fomento econômico, à civilização, enfim, de uma região assolada pelos movimentos revolucionários e pelo banditismo". Basta lembrar que, dois anos antes, em 1927, a Coluna Prestes havia passado pela região e o banditismo reinante no sertão, como o representado pelo conhecido "Bando de Leonel Rocha", que exterminava famílias inteiras, deixando a população muito insegura e, por isso, exigia uma ação enérgica das autoridades no combate a esse tipo de banditismo.

Por esse motivo, a viagem propiciou, também, um encontro entre Vargas e Konder, em Iraí, ocasião em que foi procedida a ratificação do "acordo policial", entre o Rio Grande do Sul e Santa Catarina, que permitia à polícia de cada Estado perseguir os ditos "bandidos", que se refugiavam no território do Estado vizinho.

A chegada da comitiva nas povoações era bem preparada e sempre recebida com festas pela população. No entanto, ao chegar à fronteira com a Argentina, na cidade de Dionísio Cerqueira, a comitiva constata que a cidade estava se desnacionalizando, pois tudo ali era argentino, os produtos consumidos eram argentinos, as crianças falavam espanhol e frequentavam escolas argentinas e, quando perguntadas pelos heróis nacionais, respondiam apontando figuras da história argentina e não heróis nacionais brasileiros. Mas, como relatam participantes da Viagem (D’EÇA, 1992; COSTA, 1929; BOITEUX, 1931), o avanço da Bandeira por esses territórios do Oeste ia deixando por onde passava as marcas da civilização, da organização administrativa 
e da ordem pública através de escolas, órgãos públicos, praças, meios de comunicação e planos de construção de rodovias.

Para muitos analistas, no entanto, a Viagem de 1929 (CEOM, 2005) teve um sentido mais simbólico do que real. Como uma nova bandeira desbravadora, representou um verdadeiro rito de conquista do território e de reconhecimento da soberania pública sobre uma região desconhecida, uma espécie de ato inaugural de sua incorporação simbólica. Uma viagem patriótica dos novos bandeirantes da brasilidade.

\section{REFERÊNCIAS}

BOITEUX, José Arthur. Oeste Catharinense. (De Florianópolis a Dionísio Cerqueira). Florianópolis: Livraria Central, 1931.

CEOM - Centro de Memória do Oeste Catarinense (Org.). A Viagem de 1929: oeste de Santa Catarina: documentos e leituras. Chapecó: Argos, 2005.

. Para uma história do Oeste Catarinense: 10 anos de CEOM.

Chapecó: UNOESC, 1995.

COSTA, A. Ferreira da. O Oeste Catharinense: visões e sugestões de um excursionista. Rio de Janeiro: Villas Boas e Cia, 1929.

D’EÇA, Othon Gama. Aos Espanhóis Confinantes. Florianópolis: UFSC, 1992. 